\title{
Green Technology Accounting as an Innovation to Reduce Environmental Pollution
}

\author{
Sunarmin ${ }^{\mathrm{a}, 1, *}$ \\ a Institut Ilmu Sosial dan Manajemen STIAMI, Jakarta, Indonesia \\ ${ }^{1}$ sunarmin3@gmail.com* \\ * corresponding author
}

\section{ARTICLE INFO}

\section{Article history}

Received

Revised

Accepted

Keywords

Green Tehnology;

Green Accounting

\begin{abstract}
The development of communication tools is part of the rapid development of information and communication technology. This change clearly influences communication patterns and relationships, for example in the field of work or business communication or organizational communication, education or learning communication, health communication, marketing communication primarily in marketing communication strategies, international communication, and others. Green accounting is a type of accounting that describes efforts to incorporate technology and environmental benefits and environmental costs into economic decision making or a financial outcome of a business. The aim is to find out whether green accounting technology can support the green movement of the business entity and the business continuity of the entity.

This research is a descriptive study, using the library method where research is conducted by studying and collecting data from libraries related to tools, both in the form of journals and scientific studies of research that has been published in public journals.

The results of the study concluded that the application of green technology and the impact of company activities need to be reported as a manifestation of corporate responsibility to stakeholders. The low awareness of reporting on environmental impacts is caused by several reporting constraints. The importance of environmental accounting needs to be done to improve green accounting technology that affects the positive value of environmental performance.
\end{abstract}

\section{PENDAHULUAN}

Perkembangan tehnologi yang begitu pesat, melahirkan berbagai kemudahan usaha dari berbagai bidang. Perusahaan sebagai pengguna tehnologi harus berperan aktif mengikuti perkembangan tehnologi yang selalu mengalami perubahan. Di negara-negara maju seperti Amerika, Jepang dan sebagainya, penerapan tehnologi merupakan hal yang wajib dan sudah dijadikan menu pekerjaan sehari-hari. Era industriaisasi yang berkembang begitu pesat saat ini di satu pihak menitik beratkan pada pembangunan teknologi seefisien mugkin sehingga terkadang mengabaikan aspek-aspek lingkungan. Isu mengenai pencemaran lingkungan oleh industri saat ini menjadi perhatian khusus di Indonesia bahkan di dunia, keprihatinan dunia terhadap keadaan lingkungan yang terus menerus rusak, salah satunya akibat Korporasi. Menurut data yang dikutip dari WALHI Indonesia, Korporasi bertanggung jawab paling besar atas kerusakaan Lingkungan di Indonesia. Korporasi bertanggung jawab atas 31,4 \% Kerusakan Alam di Indonesia, pembakaran hutan yang berlangsung beberapa bulan dan bukan hanya mengganggu Indonesia tetapi juga negara tetangga seperti Singapura, Malaysia, juga Brunei Darussalam Widyawati. Kesadaran masyarakat Indonesia akan pentingnya arti lingkungan mulai tumbuh secara peralahan-lahan.

Gerakan satu pohon sejuta manfaat yang ditekankan pemerintah merupakan salah satu gerakan green lingkungan yang nyata. Kesadaran ini tentunya menjadi modal dasar sebagai sistem kontrol bagi perusahaanperusahaan sehingga efek samping industrialisasi perusahaan dapat termarjinalkan. Aktualisasi kesadaran ini mulai kelihatan dengan gencarnya reaksi masyarakat terhadap perubahan yang terjadi dari suatu sistem. Pembuangan air limbah dari satu industri atau penebangan hutan yang menyimpang selalu menjadi sorotan tajam. Penerapan pemakaian tehnologi perusahaan manufaktur besar harus dapat memperhatikan dapak yang timbul dilingkungan masyarakat, baik berupa polusi udara, pencemaran limbah air dan berbagai efek yang 
timbul dari penerapan tehnologi tersebut. Masih banyak perusahaan-perusahaan manufaktur yang kurang memperhatikan dampak dari lingkungan sekitar akibat penggunaan tehnologi. Kasus pencemaran lingkungan yang terjadi di Sukoharjo Jawa Tengah oleh PT. Rayon Utama Makmur, merupakan salah satu dampak lingkungan yang diakibatkan penerapan tehnologi yang tidak tuntas. Pengelolaan biaya lingkungan dikenal dengan istilah ecoefesiency. Ekoefisiensi mengimplikasikan bahwa peningkatan efisiensi ekonomi berasal dari perbaikan kinerja lingkungan. Beberapa penyebab dan insentif untuk ekoefisiensi antara lain: (1) Permintaan pelanggan atas produk yang ramah lingkungan; (2) meningkatkan produktivitas karyawan; (3) Biaya modal dan biaya asuransi yang lebih rendah; (4) Keuntungan sosial yang signifikan sehingga citra perusahaan menjadi lebih baik; (5) Inovasi dan peluang baru; (6) Pengurangan biaya dan keunggulan bersaing (Hilton \& Platt : 2014).

Green accounting merupakan akuntansi yang di dalamnya mengidentifikasi, mengukur, menilai, dan mengungkapkan biaya-biaya terkait dengan aktivitas perusahaan yang berhubungan dengan lingkungan (Aniela, 2012). Green accounting merupakan penggabungan informasi manfaat dan biaya lingkungan kedalam macam-macam praktik akuntansi dan penggabungan biaya lingkungan kedalam keputusan bisnis (Amiruddin, 2012). Perusahaan akuntansi lingkungan berkaitan dengan dampak lingkungan bisnis, akuntansi lingkungan nasional berusaha untuk mencapai yang sama pada tingkat negara. Peraturan Yang Terkait Dengan Green Accounting adalah: (1) Undang-Undang No. 23 Tahun 1997 entang Pengelolaan Lingkungan Hidup. UU ini mengatur tentang kewajiban setiap orang yang berusaha atau berkegiatan untuk menjaga, mengelola, dan memberikan informasi yang benar dan akurat mengenai lingkungan hidup. Akibat hukum juga telah ditentukan bagi pelanggaran yang menyebabkan pencemaran dan perusakan lingkungan hidup; (2) Undang-Undang No. 40 Tahun 2007 tentang Perseroan Terbatas. UU ini mewajibkan bagi perseroan yang terkait dengan sumber daya alam untuk memasukkan perhitungan tanggungjawab sosial dan lingkungan sebagai biaya yang dianggarkan secara patut dan wajar. Pelanggaran terhadap hal tersebut akan dikenakan sanksi sesuai dengan peraturan perundang-undangan yang berlaku; (3) Keputusan Ketua Badan Pengawas Pasar Modal dan Lembaga Keuangan No: KEP- 134/BL/2006 tentang Kewajiban Penyampaian Laporan Tahunan bagi Emiten atau Perusahaan Publik.

UU ini mengatur mengenai kewajiban laporan tahunan yang memuat Tata Kelola Perusahaan (Corporate Governance) harus menguraikan aktivitas dan biaya yang dikeluarkan berkaitan dengan tanggung jawab sosial perusahaan terhadap masyarakat dan lingkungan; (4) Pernyataan Standar Akuntansi Keuangan (PSAK) No. 32 (Akuntansi Kehutanan) dan No. 33 (Akuntansi Pertambangan Umum). Kedua PSAK ini mengatur tentang kewajiban perusahaan dari sektor pertambangan dan pemilik Hak Pengusaha Hutan (HPH) untuk melaporkan item-item lingkungannya dalam laporan keuangan. Tujuan dari green accounting adalah sebagai sebuah alat managemen lingkungan dan sebagai alat komunikasi dengan masyarakat (Ikhsan: 2008).

Fungsi Green Accounting yakni, Fungsi Internal Sebagai salah satu tahap dalam sistem informasi lingkungan perusahaan, fungsi internal memungkinkan untuk mengatur biaya konservasi lingkungan dan menganalisa biaya lingkungan dengan manfaatnya, dan meningkatkan efektivitas dan efisiensi aktivitas konservasi lingkungan terkait dengan keputusan yang dibuat. Akuntansi lingkungan dapat berfungsi sebagai alat manajemen yang digunakan manajer dan unit bisnis terkait. Fungsi Eksternal, dengan mengungkapkan hasil pengukuran kuantitatif dari kegiatan konservasi lingkungan, fungsi eksternal memungkinkan sebuah perusahaan untuk mempengaruhi keputusan stakeholder, seperti konsumer, mitra bisnis, investor, dan masyarakat lokal.

Diharapkan bahwa publikasi dari akuntansi lingkungan dapat memenuhi tanggung jawab perusahaan dalam akuntabilitas stakeholderdan digunakan untuk evaluasi dari konservasi lingkungan. Intinya adalah bahwa akuntansi lingkungan bertujuan untuk meningkatkan jumlah informasi yang relevan yang dibuat untuk pihak yang memerlukan dan dapat digunakan. Kesuksesan dari akuntansi lingkungan tidak tergantung dari bagaimana perusahaan mengklasifikasikan biaya yang terjadi di perusahaan. Green Accounting saling terkait dengan dua fungsi dasar manajemen akuntansi yaitu: perencanaan dan pengumpulan data pelaporan. Tujuan green accounting adalah pengakuan dan upaya untuk mengidentifikasikan cara mengurangi negative efek dari kegiatan dan sistem pada lingkungan. Konsep akuntansi lingkungan atau green accounting sebenarnya sudah mulai berkembang sejak tahun 1970-an di Eropa, diikuti dengan mulai berkembangnya penelitian-penelitian yang terkait dengan isu green accounting tersebut di tahun 1980-an (Bebbington, 1997; Gray, dkk., 1996). 
Di negara-negara maju seperti yang ada di Eropa (Roussey, 1992) Jepang (Djogo, 2006) perhatian akan isu-isu lingkungan ini berkembang pesat baik secara teori maupun praktik. Hal ini dibuktikan dengan banyaknya peraturan terkait dengan lingkungan ini. Di Indonesia pemerintah telah mulai mendorong industri untuk melaksanakan praktek Industri hijau sejak tahun 2010. Salah satu bentuk upaya pemerintah tersebut adalah dengan diberikan penghargaan kepada industri yang menjalankan praktek industri hijau. Peningkatan jumlah Industri yang secara sukarela ikut serta dalam penilaian industri hijau oleh pemerintah ini terjadi dari tahun ke tahun. sejak tahun 2010 sampai 2014 tercatat sebanyak 160 perusahaan yang ikut serta dalam penilaian industri hijau, hal ini cukup menggembirakan namun jika dibandingkan dari total industri yang tercatatat di Indonesia sebanyak 23.370 angka ini masih kecil. Rendahnya kesadaran industri dalam penerapan industri hijau melalui green accounting karena jika dilihat secara umum bagaikan 2 sisi mata uang, di satu sisi akan mendatangkan keuntungan bagi industri namun di sisi lain seolah -olah akan menimbulkan potensi peningkatan biaya, melalui biaya lingkungan. Hal ini lah yang membuat belum banyak perusahaan yang menerapkan green accounting. Padahal jika kita analisa lebih dalam, untuk jangka waktu yang lebih panjang, penerapan green accounting akan sangat menguntungkan bagi semua pihak, baik pengusaha, konsumen maupun stakeholder lain (investor, masyarakat).

Pengorbanan perusahaan dalam mengeluarkan biaya untuk lingkungan dapat mengurangi potensi pengeluaran biaya yang lebih besar dimasa yang akan datang seperti biaya tuntutan masyarakat atas perusakan lingkungan oleh industri, resiko penutupan usaha akibat sangsi dari pemerintah dan lain sebagainya. Manfaat diterapkannya akuntansi lingkungan menurut (Pramanik, et.al., 2007) antara lain adalah sebagai berikut : (a) Mendorong pertanggungjawaban entitas dan meningkatkan transparansi lingkungan, (b) Membantu entitas dalam menetapkan strategi untuk menanggapi isu lingkungan hidup dalam konteks dimana tuntutan LSM dan masyarakat yang semakin kuat atas isu-isu terkait lingkungan. (c) Membangun citra yang lebih positif sehingga entitas dapat memperoleh pandangan yang baik dari masyarakat maupun kelompok aktivis penggiat lingkungan. (d) Mendorong konsumen untuk membeli produk ramah lingkungan dan dengan demikian membuat entitas memiliki keunggulan pemasaran yang lebih kompetitif. (e) Menunjukkan komitmen entitas terhadap usaha perbaikan lingkungan hidup. (f) Mencegah opini negatif publik mengingat perusahaan yang berusaha pada area yang berisiko tidak ramah lingkungan pada umumnya akan menerima tantangan dari masyarakat. Beberapa perusahaan yang belum menyadari dampak lingkungan atas pengoperasian operasional produksinya berakibat banyak masyarakat yang akhirnya kena imbas. Kurang pekanya manajemen suatu perusahaan dan kurang akuratnya data pelaporan yang dihasilkan oleh produk Accounting ke pada pihak yang berwenang akhirnya akan menimbulkan efek tersebut.

\section{Tujuan dan Manfaat Penelitian}

Penelitian ini merupakan penelitian deskriptif dengan menggunakan metode pustaka. Tujuan yang akan dicapai dalam penelitian ini adalah apakah benar bahwa tehnologi green accounting dapat mendukung kinerja entitas dan meningkatkan perolehan laba tanpa harus merusak ekosistem dan lingkungan sekitar. Sedangkan manfaat yang diharapkan dari penelitian ini diharapkan menjadi tambahan kajian atas penerapan tehnologi accounting dalam rangka mendukung lingkungan masyarakat yang sehat dan saling mendukung atar entitas dan masyarakat umum, yang akhirnya dapat meningkatkan kinerja perusahaan secara keseluruhan.

\section{TINJAUAN PUSTAKA}

Pendekatan penyerapan karbon oleh vegetasi merupakan salah satu cara yang dapat menurunkan akumulasi karbon di atmosfer. Untuk mengurangi emisi gas rumah kaca, salah satu cara yang paling efektif adalah dengan menggunakan fungsi pohon sebagai penyerap karbon. Hal tersebut merupakan alasan ditanamnya jenis-jenis pohon cepat tumbuh pada lahan hutan rakyat karena dapat menyerap karbon lebih cepat dibandingkan jenis-jenis pohon yang lambat dalam pertumbuhannya (Murdiyarso, 2003). Sejak didengungkan istilah global warming, setiap negara berusaha untuk mengurangi berbagai ancaman yang ditimbulkan oleh masalah-masalah lingkungan hidup. Global warming ini dikonstruksikan oleh para aktor sosial yang memiliki pengaruh dalam lingkungan sosial. Global warming kemudian"diciptakan" oleh para pembuat kebijakan dan dibantu oleh para ilmuwan dalam memberikan bukti dan data secara ilmiah. Aksi mengenai global warming di Indonesia berjalan tanpa kritikan. 
Menurut Budianto (2000) perubahan iklim global sebagai peristiwa naiknya intensitas efek rumah kaca yang terjadi karena adanya gas dalam atmosfer yang menyerap sinar panas yaitu sinar infra merah yang dipancarkan oleh bumi. Pengertian global warming adalah proses meningkatnya suhu rata-rata atmosfer, laut, dan daratan di planet ini. Pemanasan global juga bisa diartikan sebagai naiknya suhu bumi secara menyeluruh, ditandai dengan es di Kutub yang mencair dan temperatur di berbagai tempat di seluruh dunia yang cenderung naik. Hal inilah yang menjadi salah satu aspek pendorong munculnya akuntansi hijau (green accounting). Green Accouting adalah proses akuntansi yang mengintegrasikan pengakuan, pengukuran nilai, pencatatan, peringkasan, dan pelaporan informasi keuangan, sosial dan lingkungan secara terpadu dalam satu paket pelaporan akuntansi, yang berguna bagi para pemakai dalam penilaian dan pengambilan keputusan ekonomi dan non ekonomi. Laporan akuntansi tidak hanya menyajikan informasi keuangan tetapi juga informasi sosial dan lingkungan secara terintegrasi. Menurut Zulhaimi (2015), akuntansi hijau adalah realisasi tanggung jawab sosial perusahaan untuk meringankan dampak Itu.

Penerapan akuntansi hijau dapat memberikan citra yang baik bagi perusahaan.Tujuan dari green accounting adalah berusaha untuk mengurangi efek negatif dari kegiatan ekonomi dan sistem pada lingkungan hidup. Aktivitas-aktivitas dalam pelaksanaan tehnologi green accounting tentunya mengeluarkan biaya. Aktivitas tersebut merupakan biaya yang harus dibebankan oleh perusahaan yang timbul bersamaan dengan penyediaan barang dan jasa kepada konsumen. Dengan beban yang telah dialokasikan diharapkan akan membentuk lingkungan yang sehat dan terjaga kelestariannya. Kinerja lingkungan merupakan salah satu pengukuran penting dalam menunjang keberhasilan perusahaan.

Menurut Cohen dan Robbins (2011) Green accounting atau environmental accounting didefinisikan sebagai: "a style of accounting that includes the indirects costs and benefits of economic activity-such as environental effects and health consequences of businss decisions and plans" Artinya adalah akuntansi lingkungan merupakan jenis akuntansi yang memasukkan biaya dan manfaat tidak langsung dari aktivitas ekonomi, seperti dampak lingkungan dan konsekuensi kesehatan dari perencanaan dan keputusan bisnis. Beberapa alasan yang dapat mendukung pelaksanaan akuntansi lingkungan antara lain (Fasua, 2011): 1) Biaya lingkungan secara signifikan dapat dikurangi atau dihilangkan sebagai hasil dari keputusan bisnis, mulai dari perubahan dalam operasional dan pemeliharaan untuk diinvestasikan dalam proses yang berteknologi hijau serta untuk perancangan kembali produk yang dihasilkan. 2) Biaya lingkungan jika tidak mendapatkan perhatian khusus akan menjadi tidak jelas dan masuk dalam akun overhead atau bahkan akan diabaikan. 3) Banyak perusahaan telah menemukan bahwa biaya lingkungan dapat diimbangi dengan menghasilkan pendapatan melalui penjualan limbah sebagai suatu produk. 4) Pengelolaan biaya lingkungan yang lebih baik dapat menghasilkan perbaikan kinerja lingkungan dan memberikan manfaat yang signifikan bagi kesehatan manusia serta keberhasilan perusahaan. 5) Memahami biaya lingkungan dan kinerja proses dan produk dapat mendorong penetapan biaya dan harga produk lebih akurat dan dapat membantu perusahaan dalam mendesain proses produksi, barang dan jasa yang lebih ramah lingkungan untuk masa depan. 6) Perusahaan mempunyai keunggulan kompetitif yang didapat dari proses, barang, dan jasa yang bersifat ramah lingkungan. Brand image yang positif akan diberikan oleh masyarakat karena keberhasilan perusahaan dalam memproduksi barang dan jasa dengan konsep ramah lingkungan (Schaltegger dan Burritt, 2000 dalam Arisandi dan Frisko, 2011). Hal ini berdampak pada segi pendapatan produk, yaitu memungkinkan perusahaan tersebut untuk menikmati diferensiasi pasar, konsumen memiliki kecenderungan untuk bersedia membayar harga yang mahal untuk produk yang berorientasi lingkungan dengan harga premium (Aniela, 2012). 7) Akuntansi untuk biaya lingkungan dan kinerja lingkungan dapat mendukung perkembangan perusahaan dan operasi dari sistem manajemen lingkungan secara keseluruhan. Sistem seperti ini akan segera menjadi keharusan bagi perusahaan yang bergerak dalam perdagangan internasional karena adanya persetujuan berlakunya standar internasional ISO 14001. 8) Pengungkapan biaya lingkungan akan meningkatkan nilai dari pemegang saham karena kepedulian perusahaan terhadap pelestarian lingkungan. Pemegang saham perusahaan dapat lebih mudah dan cepat mendapatkan informasi dari pengungkapan tersebut sehingga dapat mempermudah pengambilan keputusan (Arisandi dan Frisko, 2011).

\section{METODOLOGI PENULISAN MAKALAH}

Penulisan penelitian ini adalah dengan menggunakan pustaka. Studi kepustakaan adalah kegiatan untuk menghimpun informasi yang relevan dengan topik atau masalah yang menjadi obyek penelitian. Beberapa sumber informasi yang digunakan dalam penelitian ini sebagai bahan studi kepustakaan diantaranya sebagai berikut: Jurnal Penelitian, dalam jurnal ini beberapa hasil penelitian terpilih diterbitkan 
sehingga dapat digunakan sebagai acuan begi perkembangan ilmu pengetahuan yang baru; Buku, buku merupakan sumber informasi yang sangat penting karena sebagian bidang ilmu yang erat kaitannya dengan penelitian diwujudkan dalam bentuk buku yang ditulis oleh seorang penulis yang berkompeten di bidang ilmunya. Surat Kabar Dan Majalah, media cetak ini merupakan sumber pustaka yang cukup baik dan mudah diperoleh di mana-mana; Internet, kemajuan teknologi membawa dampak yang sangat signifikan di bidang informasi, para peneliti dapat langsung mengakses intrernet dan mendapatkan informasi yang diinginkan dari berbagai negara dengan sangat cepat. Dalam rangka mengumpulkan data dan informasi yang valid dan akurat, mengumpulkan data yang utama (untuk mendapatkan data primer) peneliti akan melakukan kajian pustaka dan literatur-literatur pendukung seperti informasi media, internet maupun informasi pendukung lainnya yang ditelaah secara mendalam. Literatur sumber ini berguna sebagai bahan crossceck, jika ternyata ada data yang dianggap kurang valid. Studi pustaka adalah teknik pengumpulan data dengan menggunakan buku atau referensi sebagai penunjang penelitian, dan dengan melengkapi atau mencari data yang diperlukan peneliti dari jurnal, majalah, makalah, media cetak dan lain sebagainya, yang relevan dengan permasalahan yang dikaji untuk mendapatkan kejelasan konsep dalam upaya penyusunan landasan teori yang berguna dalam pembahasan. Internet searching adalah penelitian yang dilakukan dengan mengumpulkan berbagai tambahan referensi yang bersumber dari internet guna melengkapi referensi penulis berkaitan masalah yang diteliti

\section{HASIL DAN PEMBAHASAN}

Dalam akuntansi lingkungan, terdapat beberapa komponen pembiayaan yang harus dihitung, misalnya; biaya operasional bisnis yang terdiri dari biaya depresiasi fasilitas lingkungan, biaya memperbaiki fasilitas lingkungan, jasa atau fee kontrak untuk menjalankan kegiatan pengelolaan lingkungan, biaya tenaga kerja untuk menjalankan operasionalisasi fasilitas pengelolaan lingkungan, serta biaya kontrak untuk pengelolaan limbah (recycling); biaya daur ulang limbah. Biaya penelitian dan pengembangan (research and development) yang terdiri dari biaya total untuk material, tenaga ahli, dan tenaga kerja lain untuk pengembangan material yang ramah lingkungan, produk dan fasilitas pabrik. Penerapan tehnologi green accounting diharapkan dapat meningkatkan peran serta entitas terhadap kesehatan lingkungan tanpa harus membebani tambahan biaya operasional entitas dan mengurangi perolehan laba. Hasil penelitian Wiedmann dan Lenzens (2006); Bower (2010); Massound et al. (2011); Yu dan Zhao (2012); Iqbal et al. (2013); Earnhart dan Lizal (2010) serta McGuire et al. (1988), bahwa konsumen terbukti lebih memilih produk yang ramah lingkungan dan perusahaan yang fokus pada proses produksi dan intensif memproduksi produk yang ramah lingkungan terbukti memiliki kinerja lingkungan yang baik. Menurut penelitian Zulhaimi (2015) terbukti bahwa terdapat kenaikan earning dan harga saham setelah penerapan green accounting, hal ini sejalan dengan teori yang dikemukakan para ahli. Walaupun hasil pengujian t-est menunjukan tidak ada perbedaan yang signifikan antara data sebelum dan sesudah penerapan green accounting, hal ini disebabkan terbatasnya jumlah sampel yang memenuhi kriteria penilaian yaitu hanya 6 sampel.

Berdasarkan penelitian Ningsih dan Rachmawati (2017), diketahui bahwa penerapan akuntansi hijau (green accounting) memiliki dampak positif pada kinerja lingkungan. Melalui implementasi green accounting maka diharapkan lingkungan akan terjaga kelestariaannya, karena dalam menerapkan green accounting maka perusahaan akan secara sukarela mematuhi kebijakan pemerintah dimana perusahaan tersebut menjalankan bisnisnya, selain itu juga diikuti oleh meningkatnya persepsi positif dari masyarakat akan meningkatkan loyalitas masyarakat terhadap perusahaan yang pada akhirnya diikuti oleh peningkatan penjualan perusahaan dan laba peusahaan.

Panggabean dan Deviarti (2012) dalam penelitiannya mengungkapkan bahwa PT Timah belum menerapkan akuntansi lingkungan secara penuh. Padahal cukup banyak data yang dapat digunakan untuk menunjang penerapan akuntansi lingkungan. Dari penelitian Sulistyawati dan Dirgantari (2016), diketahui bahwa penerapan akuntansi hijau memiliki dampak positif pada kinerja lingkungan. Perbaikan lingkungan kinerja ini disebabkan oleh kesediaan perusahaan untuk mematuhi pemerintah kebijakan dan peraturan serta permintaan konsumen untuk suatu produk ramah lingkungan. Selain itu, penerapan akuntansi hijau juga mempengaruhi peningkatan kinerja keuangan perusahaan. Dengan peningkatan Persepsi positif masyarakat akan meningkatkan loyalitas masyarakat terhadap perusahaan, yang pada gilirannya diikuti oleh peningkatan penjualan dan laba perusahaan.

Hardianti (2017) bahwa penerapan green accounting memiliki dampak positif terhadap upaya pencegahan pencemaran lingkungan. Selain itu, penerapan green accounting juga berdampak pada 
peningkatan keberlangsungan usaha. Dengan penerapan akuntansi lingkungan atau green accounting perusahaan akan lebih memeperhatikan masalah lingkungan. Dengan memperhatikan lingkungan maka keberlangsungan usaha akan terjamin.

\section{KESIMPULAN}

Dampak aktivitas perusahaan perlu dilaporkan sebagai perwujudan tanggung jawab perusahaan kepada stakeholder. Rendahnya kesadaran pelaporan dampak lingkungan disebabkan oleh beberapa kendala pelaporannya. Pentingnya akuntansi lingkungan perlu dilakukan upaya untuk meningkatkan penerapannya. Beberapa peneliti yang konsen dalam penelitian bidang ini dapat diiktasarkan bahwa, ada sisi positip atau pengaruh atas penerapan tehnologi terhadap kinerja maupun perolehan laba, Zulhaimi (2015), Ningsih dan Rachmawati (2017).

Dengan adanya penerapan tehnologi green accounting yang konsisten ternyata mempunyai efek positif terhadap peningkatan kinerja dan perolehan laba entitas. Adanya penambahan perolehan laba tersebut keberlangsungan usaha entitas akan lebih baik dalam peningkatan pertumbuhan perusahaan. Sedangkan menurut Wiedmann dan Lenzens (2006); Bower (2010); Massound et al. (2011); Yu dan Zhao (2012); Iqbal et al. (2013); Earnhart dan Lizal (2010) serta McGuire et al. (1988), Sulistyawati dan Dirgantari (2016) dan Hardianti (2017), bahwa penerapan tehnologi green accounting mempunyai nilai positif terhadap kinerja lingkungan. Konsumen terbukti lebih memilih produk yang ramah lingkungan dan perusahaan yang fokus pada proses produksi dan intensif memproduksi produk yang ramah lingkungan terbukti memiliki kinerja lingkungan yang baik. Kinerja lingkungan merupakan hasil yang diperoleh perusahaan dari upaya pelestarian lingkungan sekitar, upaya fokus terhadap pemenuhan tanggung jawab kepada sosial dan lingkungan. Kinerja lingkungan ini dapat merupakan indikator bahwa perusahaan telah menerapkan akuntansi lingkungan.

\section{DAFTAR PUSTAKA}

Amiruddin. 2012. Etika Lingkungan Dalam Pengelolaan Lingkungan Hidup. Jurnal Nominal. Vol. 3, No. 1, Hal. 137-147

Arisandi, Desi Dan Frisko, Dianne. 2011. Green Rush In Accounting Field Of Indonesia From Different Perspectives. Papers.Ssrn

Aniela, Yoshi. 2012. Peran Akuntansi Lingkungan Dalam Meningkatkan Kinerja Lingkungan Dan Kinerja Keuangan Perusahaan. Berkala Ilmiah Mahasiswa Akuntansi - Vol 1, No. 1, Januari 2012.

Cohen, N., Dan P, Robbins. (2011). Green Business: An A-To-Z Guide. Thousand Oaks, California: Sage Publications Inc.

Fasua, Kayode Olushola. 2011. Environmental Accounting: Concept And Principles. Certified National Accountant Volume 19 Number 2 April - June, 2011.

Hilton \& Platt, Managerial Accounting. 2014 : Creating Value In A Global Business Environment, 9th Edition: Mcgraw-Hill

Ikhsan, Arfan. (2008). Akuntansi Lingkungan . Yogyakarta:Graha Ilmu

Murdiyarso, D. 2003. Protokol Kyoto: Implikasinya Bagi Negara Berkembang. Buku. Penerbit Kompas Gramedia. $200 \mathrm{Hal}$

Ningsih, Rachmawati. 2017. Implementasi Green Accounting Dalam Meningkatkan Kinerja Perusahaan. Journal Of Applied Business And Economics Vol. 4 No. 2

Panggabean, Rosinta Ria Dan Deviarti, Holly. (2012). Evaluasi Pengungkapan Akuntansi Lingkungan Dalam Perspektif Pt Timah (Persero) Tbk. Binus Business Review Vol.3 No.2 November 2012, Hal.1010-1028.

Pramanik, At.Al; (2007). Emironmental Accounting And Reporting, New Delhi, Deep Publication P.V.T Ltd. Rocky Harris.

Sulistyawati Dan Dirgantari. 2016. Analisis Pengaruh Penerapan Green Accounting Terhadap Profitabilitas Pada Perusahaan Pertambangan Yang Terdaftar Di Bursa Efek Indonesia. Jurnal Reviu Akuntansi Dan Keuangan, Vol. 6 No. 1, April 2016.

Zulhaimi, Hanifa. 2015. Pengaruh Penerapan Green Accounting Terhadap Kinerja Perusahaan (Studi Pada Perusahaan Peraih Penghargaan Industri Hijau Yang Listing Di Bei), Jurnal Riset Akuntansi Dan Keuangan Vol.3 | No.1, Universitas Pendidikan Indonesia. 
Wiedmann, T., \& Lenzen, M. (2006). Triple-Bottom-Line Accounting of Social, Economic and Environmental Indicators - A New Life-Cycle Software Tool for UK Businesses. Paper Presented at Third Annual International Sustainable Development ConferenceSustainability Creating the Culture. Perth, Scotland.

Zulhaimi, Hanifa. 2015. Pengaruh Penerapan Green Accounting Terhadap Kinerja Perusahaan. Jurnal Riset Akuntansi dan Keuangan, UPI

https://tirto.id/c8aQ, tanggal 29 Oktober 2018

http://bisnissurabaya.com/2018/05/18/akuntansi-hijau-green-accounting/

https://www.liputan6.com/global/read/3872003/global-warming-adalah-dampak-dari-efek-rumah-kaca-inicara-mengatasinya 